\title{
Use of Scanning Electron Microscopy for the Evaluation of Intestinal Epithelium Integrity
}

\author{
Marcio Heber Gomide Junior ${ }^{1}$, Elton Vinícius Sterzoㄹ, Marcos Macari², Isabel Cristina Boleli ${ }^{2 *}$
}

\begin{abstract}
This work reports the use of scanning electron microscopy to evaluate intestinal epithelium loss in broilers. Intestinal mucosa of male and female chicks submitted to prolonged period post-hatching of water and feed deprivation was evaluated. Two segments of the duodenum, jejunum and ileum were taken per bird, and routinely processed by scanning electron microscopy. Six distinct degrees of epithelium loss were determined: degree 0, normal villi without apparent extrusion; degree 1, villi presenting small areas of epithelium loss; degree 2, villi without epithelium at the apex; degree 3, villi without epithelium at the apical region; degree 4, villi without epithelium in the upper half; degree 5, lack of epithelium in the whole villus; degree 6 , loss of villi. Fasted male chicks presented only up to $38 \%$ of normal villi (degree 0 and 1 ) in the duodenum and jejunum, and $85 \%$ in the ileum, whereas fasted female chicks presented approximately $92 \%$ of normal villi in the three intestinal regions. Besides this, fasted male chicks had more accentuated degrees of epithelium loss (degrees 3 , 4, 5 and 6) than females (degree 3). Data indicated that the intestinal mucosa in male chicks presents higher susceptibility to prolonged fasting than in females. Scanning electron microscopy is shown to be a reliable routine technique to characterize and quantify intestinal epithelium loss.
\end{abstract}

Key Words: broilers, fasting, intestinal epithelium loss, scanning electron microscopy

\section{Uso de Microscopia Eletrônica de Varredura para Avaliação de Integridade do Epitélio Intestinal}

\begin{abstract}
RESUMO - Propõe-se, neste trabalho, o uso de microscopia eletrônica de varredura para avaliar perda de epitélio intestinal da mucosa intestinal de pintos machos e fêmeas submetidos a prolongado jejum pós-eclosão de água e ração. Dois segmentos do duodeno, jejuno e íleo por ave foram coletados e processados pelo método de rotina para microscopia eletrônica de varredura. Seis diferentes graus de perda de epitélio intestinal foram determinados: grau 0, vilos normais, sem extrusão; grau 1, vilos com pequenos pontos de extrusão; grau 2, vilos com perda de epitélio no ápice; grau 3, vilos com perda de epitélio na região apical; grau 4, vilos com perda de epitélio em sua metade superior; grau 5: vilos sem epitélio; grau 6: vilo quebrado. As três regiões intestinais das fêmeas apresentaram aproximadamente $90 \%$ de seus vilos normais (graus 0 e 1), enquanto nos machos ocorreu $38 \%$ de vilos normais no duodeno e jejuno e $85 \%$ no íleo. Além disso, machos apresentaram graus mais acentuados de perda de epitélio (graus 3, 4, 5 e 6) que as fêmeas (grau 3). Os dados indicaram que a mucosa intestinal de pintos machos é mais sensível a prolongado jejum pós-eclosão que a de pintos fêmeas. A microscopia eletrônica de varredura pode ser usada como um método de rotina seguro para a caracterização e quantificação de perda de epitélio intestinal.
\end{abstract}

Palavras-chave: frangos, jejum, perda de epitélio intestinal, microscopia eletrônica de varredura

\section{Introduction}

Immediately after hatching, the gastrointestinal tract of poultry undergoes morphologic and physiologic changes, which increases the surface area for digestion and absorption (Overton \& Shoup, 1964). Such changes are essential for broilers to fully express the genetic potential for weight gain and decrease the time needed to reach slaughter weight (Nitsan, 1995).
Intestinal development is related to nutrient intake, which increases intestinal diameter, and consequently intestinal weight relative to body weight (Baranyiová \& Holman, 1976).

After hatching, chicks are usually submitted to a fasting period of 24-48 hours until they are housed (Hager \& Beane, 1983). This period might be as long as 72 hours, depending on the distance between the hatchery and the farm. The fasting period post-

\footnotetext{
${ }^{1}$ Graduandos do curso de Medicina Veterinária - FCAV - UNESP, Jaboticabal, SP.

${ }^{2}$ Departamento de Morfologia e Fisiologia Animal - FCAV - UNESP, Via de Acesso Paulo Donato Castellani, Km 5, CEP: 14884-900, Jaboticabal, SP

* To whom correspondences should be adressed (icboleli@fcav.unesp.br)
} 
hatching caused dehydration and body weight loss of approximately 5-10\% (Baião \& Cançado, 1998). Moreover, birds submitted to a 72-h post-hatching fasting do not show compensatory weight gain during refeeding, and have lower body weight at market age (42 days) when compared to birds not submitted to fasting (Almeida, 2002).

The intestinal mucosa responds to the presence or absence of exogenous agents by changing villus height, crypt depth, cells proliferation, villus density and number of dead cell and epithelium loss. Usually, the first four parameters are evaluated. Yamauchi et al. (1996) and Shamoto \& Yamauchi (2000) reported decrease in the height of intestinal villi in birds fasted for 24-72-h. Baranyiová \& Holman (1976) found a decrease in the height and diameter of villi, as well as in the turnover of the intestinal epithelium cells. The loss of intestinal epithelium has not been examined due to the lack of appropriated methods. However, qualitative and quantitative evaluations of epithelium loss are very important, considering that they permit a reliable evaluation of the digestive and absorptive capacity of the intestine, besides the evaluation of damages caused to the intestinal mucosa by fasting or pathogenic agents.

Some studies have shown gender influences on growth and muscle development of chicken embryos (Burke, 1994; Burke \& Sharp, 1989; Henry \& Burke, 1997; Mitchell \& Burke, 1995). Besides, it is known that female and male broiler chicks present distinct growth rate in the first weeks post-hatching. Thus, the question arises whether female and male chicks would respond differently to water and feed deprivation.

The present study reports the utilization of scanning electron microscopy to evaluate qualitatively and quantitatively the loss of intestinal epithelium in male and female chicks submitted to prolonged posthatching water and feed deprivation.

\section{Material and Methods}

\section{Incubation and fasting}

Fertile broiler eggs produced by 42 -week-old Cobb 500 breeders were obtained from a commercial hatchery. Eggs $(60-71 \mathrm{~g})$ were incubated at $37.8^{\circ} \mathrm{C}$ and $60 \%$ relative humidity in an incubator with automatic temperature control and egg turning (1 turn/h) (Premium Ecológica, IP 120).

Immediately after hatching, chicks were individually identified and kept at $32^{\circ} \mathrm{C}$ in the hatching baskets (Premium Ecológica, NP 120). The chicks were submitted to a prolonged period $(86 \mathrm{~h})$ of water and feed deprivation.

Sample collection

At the end of the fasting period, chicks were killed by neck dislocation. Three-cm were taken from the duodenum, jejunum and ileum of 5 females and 5 males. The samples were processed and analyzed by scanning electron microscopy as described below. Birds were winged-sexed, and sex was confirmed by the number of gonads (two in males and one in females).

\section{Scanning electron microscopy}

Intestinal samples were longitudinally opened, stretched and briefly washed with $0.1 \mathrm{M}$ phosphate buffer (pH 7.4) to remove intestinal contents. Samples were fixed for $24 \mathrm{~h}$ at $4^{\circ} \mathrm{C}$ in $2 \%$ glutaraldehyde in phosphate buffer. After fixing, samples were washed with phosphate buffer and post-fixed for $2 \mathrm{~h}$ in $1 \%$ osmium tetroxide in phosphate buffer. The samples were washed again with phosphate solution and dehydrated in a graded ethanol series $(50,60,70,80$, $90,100 \%$ with two baths in $100 \%$ ethanol). Subsequently, the samples were submitted to critical point drying and sputter-coating with gold. Samples were examined and photographed using a Jeol JSM 5410 scanning electron microscope.

Three electron-micrographs of each region (duodenum, jejunum and ileum) were analyzed from each bird., with a total area of 1,157,742.4 $\mu \mathrm{m}^{2}$.

\section{Analyzed parameters}

The degrees of epithelium loss were described and used to characterize the samples qualitatively. Each electron-micrograph was evaluated quantitatively by the number of villi with and without epithelium loss. Also, the number of villi with epithelium loss was expressed as a percentage of the total number of villi, considering each degree of epithelium loss.

\section{Statistical analysis}

Data were analyzed by Chi-Square test, at a level of significance of 5\% (SAS, 2000).

\section{Results and Discussion}

Characterization of the epithelium loss degrees

Six different degrees of epithelium loss were identified in the electron-micrographs of intestinal mucosa of fasted male and female chicks. The degrees 
reflected an increasing loss of epithelial and/or connective tissue loss, the highest level considering total villus loss, as described below:

- Degree 0: no apparent epithelium loss (normal villi) (Figure 1A, arrow)

- Degree 1: small areas of epithelium loss at the tip or at different areas along the villus (normal extrusion) (Figure 1A, arrow head)

- Degree 2: epithelium loss with exposure of the connective tissue at the apex of the villus (Figure 1B)

- Degree 3: epithelium loss of the apical portion of the villus, exposing the connective tissue, resembling the tip of a tongue (Figure 1C)
- Degree 4: marked epithelium loss in the upper half of the villus and connective tissue exposure (Figure 1D)

- Degree 5: lack of epithelium in the entire villus, and exposure of connective tissue, resembling a totally exposed tongue (Figure 1E)

- Degree 6: villus loss (resembling a broken villus) (Figure 1F)

The high plasticity of the intestinal mucosa is a special feature that allows the response to exogenous agents, such as food presence or absence, and to pathologic situations. Such response consists of changes in villus height and crypt depth, villus density and rate of epithelial loss (Boleli et al., 2002). Villus
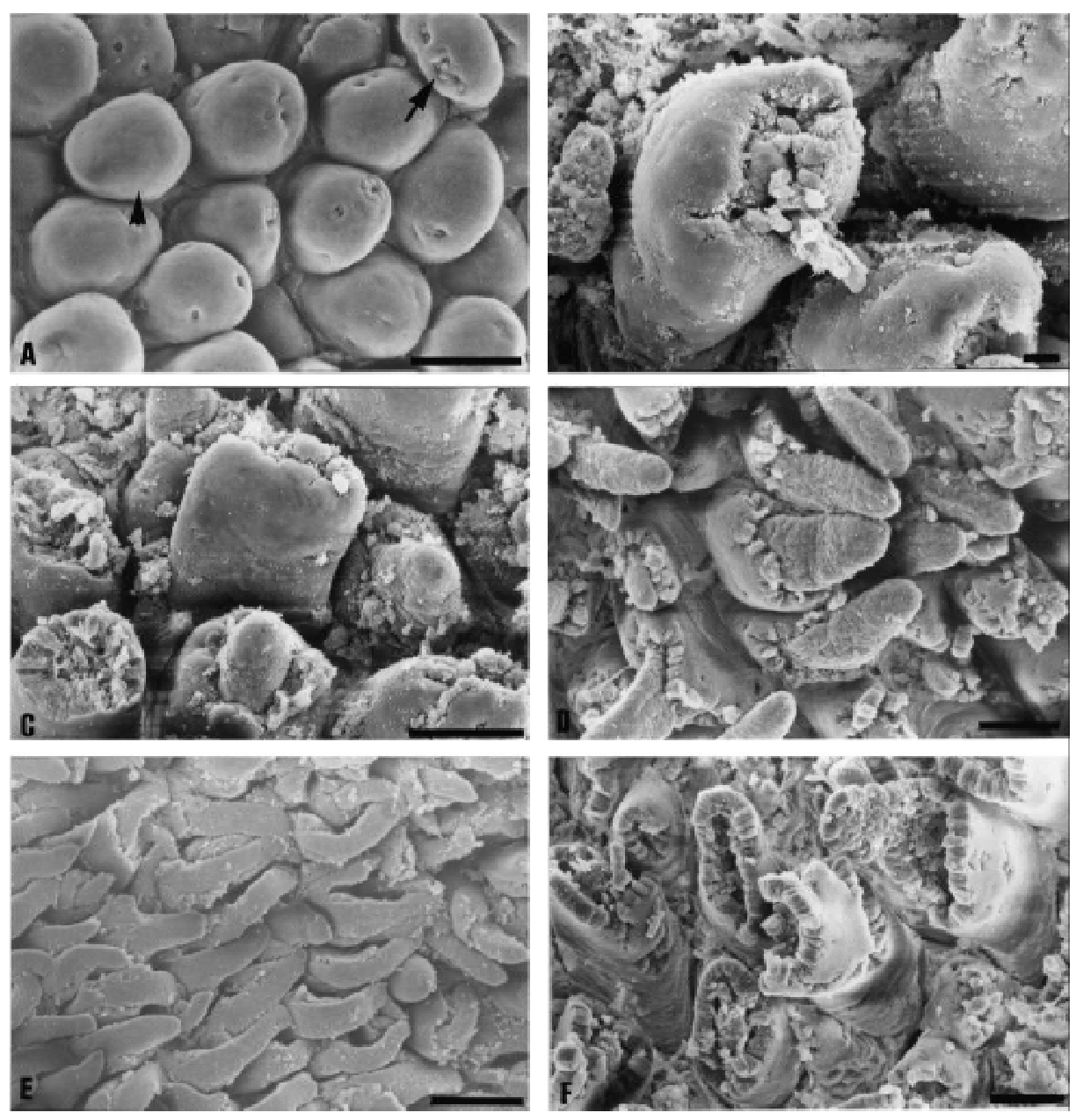

Figure 1 A-F - Degrees of epithelium loss of chick intestinal villi. A: degree 0 and 1, B: degree 2, C: degree 3, D: degree

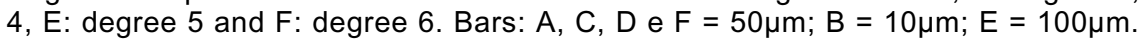


height and crypt depth are frequently evaluated, providing data relative to villous growth and regression. Villus density is also currently evaluated to characterize the intestinal mucosa development (Yamauchi et al., 1995, 1996; Maiorka, 2002; Fischer da Silva; 2001). On the other hand, despite being an important parameter in the evaluation of intestinal mucosa integrity, epithelial loss has not been analyzed. Scanning electron micrographs in the present study made possible to characterize the intestinal epithelium losses occurred in chicks as a result of prolonged post-hatching deprivation of water and feed deprivation.

\section{Quantification of epithelium losses}

The villi that presented degrees 0 and 1 of epithelium loss were considered normal, whereas those presenting degrees 2-6 were classified as damaged villi. Female chicks submitted to prolonged post-hatching fasting presented a significantly higher percentage $(\mathrm{p}<0.05)$ of normal villi $(91.9 \%, 92.9 \%$, $94.4 \%)$ than of damaged villi $(8.1 \%, 7.1 \%, 5.6 \%)$, in the duodenum, jejunum and ileum, respectively (Fig.2). However, in male chicks, significantly higher $(\mathrm{p}<0.05)$ percentage of normal villi occurred in the ileum $(88.2 \%)$, but not in the duodenum $(37.1 \%)$ and jejunum (34.4\%) (Figure 2).

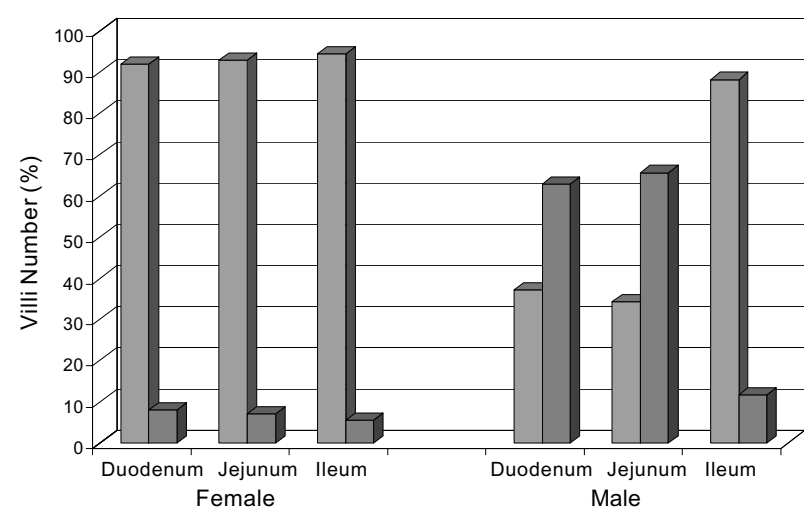

Figure 2 - Total number of villi (\%) without (degree 0 and 1 , hatched columns) or with (degrees 2-6, filled columns) epithelium loss, in the duodenum, jejunum and ileum of male and female chicks fasted during the first 86 hours post-hatching.

R. Bras. Zootec., v.33, n.6, p.1500-1505, 2004
In males, the percentage of villi with different degrees of epithelium loss - differed significantly $(p<0.05)$ in the three intestinal regions. In the duodenum, $21.7 \%$ of the villi had no epithelium loss (degree 0 ); $15.4 \%$ of the villi had epithelium loss considered as degree $1 ; 20.2 \%$ as degree $2 ; 16.6 \%$ as degree $3 ; 11.8 \%$ as degree $4 ; 7.9 \%$ as degree 5 ; and $6.3 \%$ as degree 6 (Figure 3 ). In the jejunum, $18.29 \%$ of the villi had no epithelium loss (degree 0 ); $16 \%$ had epithelium loss considered as degree $1 ; 14.4 \%$ as degree $2 ; 11.4 \%$ as degree $3 ; 13.0 \%$ as degree 4 ; $26.8 \%$ as degree 5 (Figure 3 ). In the ileum, $71.1 \%$ of the villi were normal (degree 0 ); $17.1 \%$ presented epithelium loss considered as degree $1 ; 4.5 \%$ as degree $2 ; 6.1 \%$ as degree 3 ; almost $0 \%$ as degree 4 , 5 e 6 (Figure 3). However, in the female chicks, all regions presented a significantly higher $(\mathrm{p}<0.05)$ percentage of villi without extrusion (degree $0,80 \%$ ) than of villi with small extrusion (degree $1,15 \%$ ), and both values (percentage of degrees 0 and 1) were significantly higher $(\mathrm{p}<0.05)$ than the percentage of villi presenting the other degrees of epithelium loss (degrees 2-6, 4-5\%) (Figure 4).

Epithelial loss evaluation showed that the intestinal mucosa of male chicks, as opposite to females had

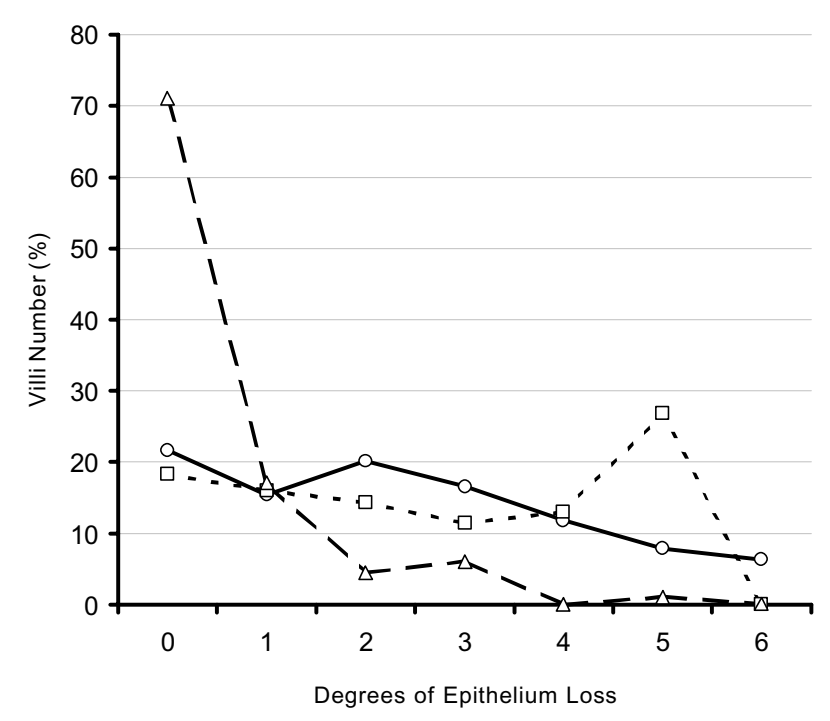

Figure 3 - Total number of villi (\%) presenting epithelium loss (degrees 0-6) in the duodenum (solid line with circles), jejunum (hatched line with squares) and ileum (hatched line with triangles) of male chicks fasted during the first 86 hours post-hatching. 
higher sensitivity to prolonged post-hatching fasting. Furthermore, it was showed that the three evaluated intestinal regions presented about $90 \%$ of normal villi (degree 0 and 1) in females, as well as the ileum in males. On the other hand, in males, the duodenum and the jejunum were highly susceptible to post-hatching fasting and presented approximately $60 \%$ of damaged villi (degrees 2-6). Sex-specific differences were also seen when other parameters were considered, such as body weight and the number and type of muscle fibers in broilers (Henry \& Burke, 1997), embryos and chicks of laying strains (Burke \& Sharp, 1989; Burke et al., 1990; Mitchell \& Burke, 1995) and turkeys (Whiting \& Peste, 1993; Burke, 1994). Differences in the response of the intestinal regions were also observed by Fisher da Silva (2001) and Maiorka (2002). However, factors responsible for sexspecific responses of the intestinal mucosa to prolonged post-hatching fasting still have to be established.

Post-hatching fasting reduces cell turnover and intestinal villus height (Baranyová \& Holman, 1976; Yamauchi et al., 1996) due to body water loss caused by evaporation via respiration (Baião \& Aguilar, 2001).

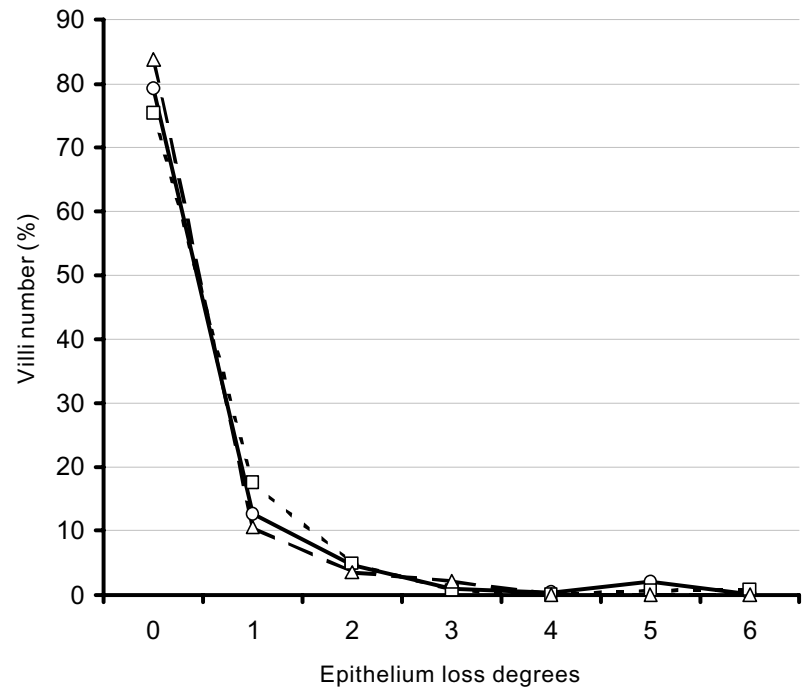

Figure 4 - Total number of villus (\%) presenting epithelium loss (degrees 0-6) in the duodenum (solid line with circles), jejunum (hatched line with squares) and ileum (hatched line with triangles) of female chicks fasted during the first 86 hours post-hatching.
This suggests that lower body weight at market age of birds submitted to a 72-h post-hatching fasting period as compared to non-fasted chicks (Nir \& Levanon, 1993; Almeida, 2002) is due to a lower development of the intestinal villi. In such context, data obtained in the present study indicate that the substantial epithelium loss observed in the digestive and absorptive intestinal regions of fasted male broilers may be largely responsible for the lower broiler performance after long fasting observed by Almeida (2002).

According to Uni et al. (1998), proliferation of enterocytes in the jejunum of chicks is not confined to the crypt, but occurs also along the villus. This indicates that chicks presenting degrees 3, 4, 5 and 6 of epithelium loss in the jejunum might have a marked loss of the potential for cell proliferation in this intestinal region and, consequently, a significant reduction in the villus development.

\section{Conclusion}

The present study introduces scanning electron microscopy as a routine method for the evaluation of intestinal mucosa integrity of broilers. The technique permitted not only to characterize but also quantify the damages in the intestinal epithelium, which are important parameters so that reliable intestinal evaluation or diagnosis can be made.

\section{Literature Cited}

ALMEIDA, J.G. Efeito do intervalo de tempo entre o nascimento e o alojamento no desempenho características de carcaça e viscerais de frangos de corte provenientes de matrizes de diferentes idades. Jaboticabal: Universidade Estadual Paulista, 2002. 77p. Dissertação (Mestrado em Zootecnia) - Universidade Estadual Paulista, 2002.

BAIÃO, N.C.; CANÇADO, S.V. Efeito do intervalo entre nascimento e o alojamento de pintos sobre o desempenho dos frangos. Arquivos Brasileiros de Medicina Veterinária e Zootecnia, v.50, p.191-194,1998.

BAIÃO, N.C.; AGUILAR, C.A.L. Impacto do tempo de alojamento do pintinho de corte sobre a produção do frango. In: Conferência APINCO 2001 de Ciência e Tecnologia Avícola, Campinas. Anais... Campinas: Fundação Apinco de Ciência e Tecnologia Avícolas, 2001. p.125-140.

BARANYOVÁ, E.; HOLMAN, J. Morphological changes in the intestinal wall in fed and fasted chickens in the first week after hatching. Acta Veterinária, v.45, p.151-158, 1976.

BOLELI, I.C.; MAIORKA, A.; MACARI, M. Estrutura funcional do trato digestório. In: MACARI, M.; FURLAN, R.L.; GONZALES, E. (Eds.) Fisiologia aviária aplicada a frangos de corte. 2.ed. Jaboticabal: Universidade Estadual Paulista, 2002. p.75-98. 
BURKE, W.H. Sex differences in weight of turkey embryos. Poultry Science, v.73, p.749-753, 1994.

BURKE, W.H.; SHARP, P.J. Sex differences in body weight of chicken embryos. Poultry Science,v.68, p.805-810, 1989.

BURKE, W.H.; ARBTAN, K.D.; SNAPIR, N. The role of plasma thyroid hormones in the regulation of body weight of Single Comb White Lerghorn and broiler embryos. Poultry Science, v.69, p.1388-1393, 1990.

FISHER DA SILVA, A.V. Efeitos da restrição alimentar precoce e da glutamina no desempenho e na mucosa intestinal em frangos. Jaboticabal: Universidade Estadual Paulista, 2001. 77p. Tese (Doutorado em Zootecnia) Universidade Estadual Paulista, 2001.

HAGER, J.E.; BEANE, W.L. Posthatch incubation time on early growth of broiler chicks. Poultry Science, v.62, p.247-254, 1983.

HENRY, M.H.; BURKE, W.H. Sexual Dimorphism in broiler chick embryos and embryonic muscle development in late incubation. Poultry Science, v.77, p.728-736, 1997.

MAIORKA, A. Efeitos da idade da matriz, do jejum, da energia da ração e da glutamina sobre o desenvolvimento da mucosa intestinal e atividade enzimática do pâncreas de pintos de corte. Jaboticabal: Universidade Estadual Paulista, 2002. 103p. Tese (Doutorado em Zootecnia), Universidade Estadual Paulista, 2002.

MITCHELL, R.D.; BURKE, W.H. Genotype and sexual influences on growth and muscle development of chicken embryos. Growth Development Aging, v.59, p.31-44, 1995.

NIR, I.; LEVANON, M. Research note: effect of post-hatch holding time performance and residual yolk and liver composition. Poultry Science, v.72, p.1994-1997, 1993.

NITSAN, Z. The development of digestive tract in posthached chicks. In: EUROPEAN SYMPOSIUM ON POULTRY NUTRITION, 10., 1995, Antaya. Proceedings... Antaya: 1995. p.21-28.
OVERTON, J.; SHOUP, J. Fine structure of cell surface specializations in the maturing duodenal mucosa of the chick. Journal of Cell Biology, v.21, p.75-82, 1964.

STATISTICAL ANALYSES SYSTEM - SAS. User's guide: statistics. Cary: 2000.

SHAMOTO, K.; YAMAUCHI, K. Recovery responses of chick intestinal villus morphology to different refeeding procedures. Poultry Science, v.79, p.718-723, 2000.

UNI, Z.; PLATIN, R.; SKLAN, D. Cell proliferation in chicken intestinal epithelium occurs both in the crypt and along the villus. Journal of Comparative Physiology, v.168, p. 241247, 1998.

YAMAUCHI, K.; YAMAMOTO, K.; ISSHIKI, Y. Morphological alterations of the intestinal villi and absorptive epithelium cells in each intestinal part in fasted chickens. Japanese Poultry Science, v.32, p.241-251, 1995.

YAMAUCHI, K.; KAMISOYAMA, H.; ISSHIKI,Y. Effects of fasting and refeeding on structures of the intestinal villi and epithelial cells in White Leghorn hens. British Poultry Science, v.37, p.909-921, 1996.

WHITING, T.S.; PESTI, G.M. Effects of the dwarfing gene (dw) on egg weight, chick weight and chick weight: egg weight ratio in a commercial broiler strain. Poultry Science, v.62, p.425-429, 1983. 